\title{
CURRENT RECORDS OF THE MEXICAN LONG-TONGUED BAT, CHOERONYCTERIS MEXICANA, IN BAJA CALIFORNIA, MEXICO
}

\author{
Ruben Couoh-de la Garza ${ }^{1}$, Emma Flores-Rojas ${ }^{1}$, \\ Nazdry Briones-Escobedo ${ }^{1}$, Eiracitlalli Hernández-del Angel ${ }^{1}$, \\ Roberto Martínez-Gallardo ${ }^{1}$, and Juana Claudia Leyva Aguilera ${ }^{1}$
}

Key words: Long-tongued bat, Baja California, Mexico, records.

The long-tongued bat (Choeronycteris mexicana) is a nectar-eating species that inhabits southern California, southern Arizona, southwestern New Mexico, northern and central Mexico including Baja California and the Tres Marías Islands, El Salvador, and Honduras (Hall 1981, Cryan and Bogan 2003). The usual altitudinal range is from about $300 \mathrm{~m}$ to $2400 \mathrm{~m}$ (Arroyo-Cabrales et al. 1987). This species is found in a wide variety of habitats ranging from arid thorn scrub (Axtell 1962, Baker and Greer 1962, Baker and Womochel 1966, Matson et al. 1978) to tropical deciduous forest (Davis and Russell 1954) and mixed oak-conifer forest (Matson and Patten 1975, Arroyo-Cabrales et al. 1987). In 1947 Huey collected 4 specimens (2 females and 2 males) from Rancho la Ramona, $8 \mathrm{mi} \mathrm{N}$ of Santa Catarina (San Diego Natural History Museum [SDNMH]), and 4 specimens ( 2 females and 2 males) in the Aguajito, Turquesa Mine (SDNHM). All these records were reported by Huey (1963). In 1961 Parrish and Banks collected 2 specimens (1 female and 1 male) in Turquesa Mine, E of El Rosario (SDNHM). In 1947 Villa-R reported 2 bats 5.5 mi E of Aguajito (California Academy of Science [CAS]) and 3 specimens in Desengaño mine, 14 mi NNE of Punta Prieta (CAS). And in 1969 Bostic collected 3 specimens (2 females and 1 male) $1.7 \mathrm{mi} \mathrm{SW}$ of Santa Catarina (SDNHM). California records have largely been from urban habitats in San Diego (Olson 1947).

We provide new information on recent records of C. mexicana at 3 localities in Baja California (Table 1); these specimens will be deposited in the Collection of Vertebrates (Mammals), Facultad de Ciencias, Universidad
Autónoma de Baja California (UABC), Ensenada, México. Recent records of C. mexicana in Baja California are (1) an adult female (UABC-219) captured 3 October 2003 in an olive acreage at the Cañón de Doña Petra, $2.3 \mathrm{mi} \mathrm{NE}$ of Ensenada city $\left(31^{\circ} 53^{\prime} 00^{\prime \prime} \mathrm{N}\right.$, $\left.116^{\circ} 20^{\prime} 00^{\prime \prime} \mathrm{W}\right)$, by E. Hernández-del Angel, F. Casillas-Figueroa, N. Briones-Escobedo, and R. Couoh-de la Garza; (2) an adult female (UABC211) and skull (UABC-220) collected 17 December 2003 in the Sauzalito mine near El Rosario, $0.3 \mathrm{mi} \mathrm{NE}$ of Arenoso $\left(30^{\circ} 05^{\prime} 00^{\prime \prime} \mathrm{N}\right.$, $\left.115^{\circ} 22^{\prime} 00^{\prime \prime} \mathrm{W}\right)$, by E. Flores-Rojas, N. BrionesEscobedo, R. Couoh-de la Garza, and R. Martínez-Gallardo; (3) 7 specimens captured 17 December 2003 in the abandoned Cajoncito gold mine, $1.4 \mathrm{mi} \mathrm{NNW}$ of $\mathrm{El}$ Arenoso $\left(30^{\circ} 07^{\prime} 00^{\prime \prime} \mathrm{N}, 115^{\circ} 21^{\prime} 00^{\prime \prime} \mathrm{W}\right)$, by E. Flores-Rojas, N. Briones-Escobedo, R. Couoh-de la Garza, and R. Martínez-Gallardo.

These recent records of $C$. mexicana indicate the northernmost presence of this species in Baja California, México (Fig. 1). This survey established a body of information that will be useful to future population monitoring efforts. Considering their ecological importance and susceptibility to population decline, bat populations should be effectively monitored (O'Shea and Bogan 2000). Because of the limited number of roost sites involved in this study, we recommend that these areas be surveyed every 2-3 years and protected from disturbance. Further research into the habitat needs, food habits, pollination role, survivorship, and distribution of C. mexicana would enhance our understanding of these potentially important migratory pollinators. 
TABLE 1. Body and cranial measurements $(\mathrm{mm})$ of recent specimens of Choeronycteris mexicana from 5 localities in Baja California, México.

\begin{tabular}{lcccccccc}
\hline & & & & & \multicolumn{4}{c}{ Cranial measures (mm) } \\
\cline { 6 - 9 } $\begin{array}{l}\text { Catalog } \\
\text { Number }\end{array}$ & $\begin{array}{c}\text { Weight } \\
(\mathrm{g})\end{array}$ & $\begin{array}{c}\text { Total Length } \\
(\mathrm{mm})\end{array}$ & Sex & $\begin{array}{c}\text { Forearm } \\
(\mathrm{mm})\end{array}$ & $\begin{array}{c}\text { Condylobasal } \\
\text { length }\end{array}$ & $\begin{array}{c}\text { Zygomatic } \\
\text { breadth }\end{array}$ & $\begin{array}{c}\text { Maxillary } \\
\text { tooth-row }\end{array}$ & $\begin{array}{c}\text { Interorbital } \\
\text { breadth }\end{array}$ \\
\hline 211 & 15.7 & 51.2 & $\mathrm{~F}$ & 43.4 & 29.3 & 9.5 & 12.2 & 3.6 \\
212 & 16.0 & 53.3 & $\mathrm{~F}$ & 46.4 & 29.8 & 9.7 & 11.5 & 3.9 \\
213 & 16.14 & 47.5 & $\mathrm{~F}$ & 45 & 29.1 & 9.5 & 13.1 & 3.6 \\
214 & 16.68 & 50.2 & $\mathrm{~F}$ & 44.3 & 29.8 & 9.0 & 13.5 & 3.8 \\
215 & 14.7 & 48.4 & $\mathrm{~F}$ & 43.5 & 28.9 & 9.3 & 13.1 & 3.6 \\
216 & 14.33 & 47.8 & $\mathrm{~F}$ & 43 & 29.0 & 9.4 & 13.1 & 3.9 \\
217 & 15.0 & 52.4 & $\mathrm{~F}$ & 44.4 & 29.8 & 9.1 & 13.4 & 3.8 \\
218 & 15.5 & 51.5 & $\mathrm{~F}$ & 45.3 & 29.2 & 9.9 & 14.1 & 3.9 \\
219 & 12.71 & 80.8 & $\mathrm{~F}$ & 42.5 & 29.2 & 9.4 & 13.7 & 4.0 \\
220 & - & - & - & - & 25.8 & 8.8 & 10.4 & 3.8 \\
\hline
\end{tabular}

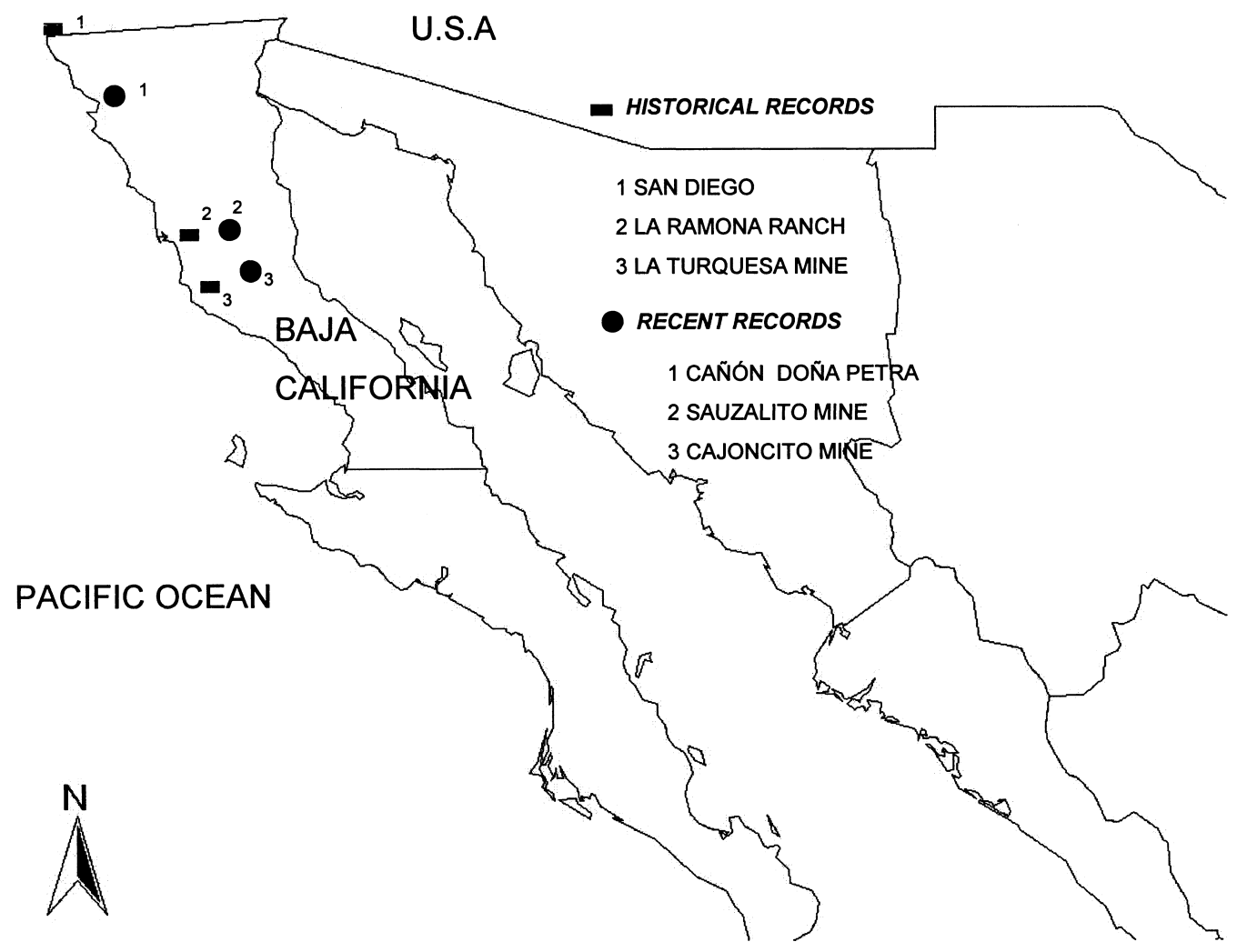

Fig. 1. Historical and recent records of Choeronycteris mexicana in Baja California, México. The map shows the area between $26^{\circ}-34^{\circ} \mathrm{N}$ latitude and $112^{\circ}-117^{\circ} \mathrm{W}$ longitude. 


\section{Literature Cited}

Arroyo-Cabrales, J., R.R. Hollander, and J. Knox Jones, JR., 1987. Choeronycteris mexicana. Mammalian Species 291:1-5.

AxtelL, R.W. 1962. An easternmost record for the bat Choeronycteris mexicana from Coahuila, México. Southwestern Naturalist 7:76.

Baker, R.H., And J.K. Greer. 1962. Mammals of the Mexican state of Durango. Publications. Museum. Michigan State University. Biological Series 2:25-154.

BaKer, R.H., AND D. Womochel. 1966. Mammals from southern Oaxaca. Southwestern Naturalist 11:306.

Cryan, P.M., And M.A. Bogan. 2003. Recurrence of Mexican long-tongued bats (Choeronycteris mexicana) at historical sites in Arizona and New Mexico. Western North American Naturalist 63:314-319.

Davis, W.B., AND R.J. Russell, JR. 1954. Mammals of the Mexican state of Morelos. Journal of Mammalogy 35: 63-80.

HaLL, E.R. 1981. The mammals of North America. 2nd edition. John Wiley \& Sons, New York.
Huey, L.M. 1963. The mammals of Baja California, México. Transactions of the San Diego Society of Natural History 13:87-165.

Matson, J.O., and D.R. Patten. 1975. Notes of some bats from the state of Zacatecas, México. Contributions in Science. Natural History Museum of Los Angeles County 263:1-12.

Matson, J.O., R.H. Baker, and J.K. Greer. 1978. New records of mammals in the state of Zacatecas, México. Southwestern Naturalist 23:154-156.

Olson, A.C., JR. 1947. First records of Choeronycteris mexicana in California. Journal of Mammalogy 28: 183-184.

O’ ShEa, T.J., AND M.A. Bogan, EDITORs. 2000. Interim report of the Workshop on Monitoring Trends in U.S. Bat Populations: problems and prospects. U.S. Geological Survey, Fort Collins Science Center, Fort Collins, CO. Available from: http://www.fort.usgs.gov /products/pubs/20005/20005.asp

Received 4 October 2004 Accepted 17 June 2005 